\title{
Revenue Forecasting Practices: Differences across Countries and Consequences for Forecasting Performance
}

\author{
THIESS BUETTNER \\ BJOERN KAUDER
}

CESIFo Working PAPER No. 2628

CATEgory 1: Public FinANCE

APRIL 2009
An electronic version of the paper may be downloaded
- from the SSRN website:
- from the RePEc website:
- from the CESifo website:
www.SSRN.com
www.RePEc.org
www.CESifo-group.org/wp




\title{
Revenue Forecasting Practices: Differences across Countries and Consequences for Forecasting Performance
}

\begin{abstract}
This paper reviews the practice and performance of revenue forecasting in selected OECD countries. While the mean forecast errors are small in most countries, the precision of the forecasts measured by the standard deviation of the forecast error differs substantially across countries. Based on a comparison of forecasting practices we show that these differences can be attributed to a large part to differences in the timing of the forecasts and in the tax structure. In addition, we find some evidence that differences in methods and institutions also matter for the forecasting precision. In particular, we find that the use of macroeconomic models as well as the independence of revenue forecasting are associated with a lower standard deviation of the forecast error.
\end{abstract}

JEL Code: H68, H11.

Keywords: revenue forecasting, international comparison, OECD countries, forecast error.

Thiess Buettner

Ifo Institute for Economic Research at the University of Munich

Poschingerstrasse 5

81679 Munich

Germany

buettner@ifo.de
Bjoern Kauder

Ifo Institute for Economic Research at the University of Munich

Poschingerstrasse 5

81679 Munich

Germany

kauder@ifo.de

February 2009

The authors are grateful to many people that helped to collect information about revenue forecasting in different countries, in particular to Sabatino Alimenti, Frits Bos, John Conlon, Carl Emmerson, Martin Keene, Maria Rosaria Marino, Toru Oe, Tim Pike, Anton Rainer, Mark Rider, Ken Shinohara, Christian Valenduc, and David Wildasin. However, the authors are fully responsible for any remaining errors. 


\section{Introduction}

Revenue forecasting is an essential part of budgeting in the public sector and, hence, all countries make some efforts to obtain reliable figures for the expected revenues. Of course, preparing revenue forecasts is associated with some uncertainties, such as macroeconomic risks or uncertainties about the tax law and its enforcement. Furthermore, there are changes in tax laws and structural changes in the economy that make forecasting even more difficult. Another possible uncertainty lies in repercussions of the revenue developments on public spending and the associated macroeconomic consequences. Although these challenges are faced by forecasters in all countries, there are significant differences in the practice of revenue forecasting. Not only are there differences in methodologies used. The countries also show important differences in the institutional aspects of revenue forecasting. In several countries the government is directly in charge, other countries assign the forecasting task to research institutes, and emphasize the independence of forecasting. This raises the question of whether the forecasting performance is affected by the different practices and methodologies involved. Moreover, given the efforts that some countries devote to ensuring independence from possible government manipulation, it would be interesting to know whether this independence has a noticeable impact on the quality of the forecasts.

The performance of revenue forecasting and its possible determinants including institutional aspects have been explored in the literature in different directions (for a recent survey see Leal, Perez, Tujula, and Vidal, 2008). Revenue forecasting has received most attention in the context of US states' revenue forecasts. Feenberg, Gentry, Gilroy, and Rosen (1989), for instance, provide evidence that state revenue forecasts are biased downwards. More recently, Boylan (2008) finds evidence 
for biases associated with the electoral cycle. Bretschneider, Gorr, Grizzle, and Klay (1989) focus on the accuracy of revenue forecasts and find that accuracy is higher in US states with competing forecasts from executive and legislative branches. Moreover, Krause, Lewis, and Douglas (2006) provide some evidence that the accuracy of states' revenue fund estimates depend systematically on the staffing of the revenue forecasting teams. As Bretschneider et al. note, however, the design of US state governments has specific features such as balanced-budget rules and a rivalry between executive and legislative branches of government which may explain some of these results.

International comparisons have mainly centered around the broader issue of budget and deficit forecasting. Recently, the relative performance of deficit forecasts among the EU countries has been examined in the context of the Stability and Growth Pact. Jonung and Larch (2006), for instance, have discussed the political biases in the output forecasts used for deficit projections. International comparisons concerned with the more narrow issue of revenue forecasting, however, focus on developing countries (e.g., Kyobe and Danninger, 2005) where institutions relevant for revenue forecasting are underdeveloped (Danninger, 2005).

Against this background this paper provides an analysis of the performance of revenue forecasting and its determinants among twelve OECD countries. The selection of countries aims at capturing the seven largest OECD economies (United States, Japan, Germany, Italy, UK, France, and Canada). Some further countries were added where detailed information about revenue forecasting was available. This includes selected countries in Western Europe (Austria, Belgium, Ireland, Netherlands) and New Zealand.

What turns out is that the cross-country differences in the performance of revenue forecasting are 
to some extent driven by country characteristics such as the tax structure both in terms of the sheer number of taxes as well as with regard to the importance of corporation and income taxes. Also differences in the timing of the forecasts prove important. Controlling for these differences we also find that the precision of revenue forecasting increases with the independence of forecasts from possible government manipulation and if the revenue forecast is embedded in a macroeconomic model.

The following section presents some descriptive statistics on the performance of revenue forecasting in the sample of OECD countries. Section 3 provides a brief overview on the different conditions that forecasters face in these countries. Section 4 gives a short account of the forecasting methodologies used in the various countries. Section 5 provides an overview of the institutional aspects of the forecasting task among the selected OECD countries and sets up a simple indicator of the independence of revenue forecasting. Section 6 presents empirical evidence on the determinants of forecasting performance. Section 7 provides our conclusions.

\section{Forecasting Performance}

A common way to assess the quality of revenue forecasts is to consider the prediction error, that is the difference between predicted and realized revenues. A smaller prediction error is then usually regarded as a better forecast quality. However, it should be noted that revenue forecasts are basically used to indicate the revenue constraint that needs to be taken into account in the preparation of the public budget. Often, the budget will include expenditures that have a direct or indirect effect on tax revenues. While foreseeing these implications might result in a smaller forecast error, it 
is not clear whether this constitutes an improvement of a forecast that basically aims at providing the policy maker with information about the revenue constraint. In the discussion of the revisions of US revenue forecasts, therefore, policy changes are distinguished from (macro-)economic and so-called technical sources (Auerbach, 1999) of forecast errors, where the latter may refer to tax administration or evasion, for instance. However, for most countries a decomposition is not available. Therefore, the quantitative analysis presented below is based on the overall forecast error.

The one-year-ahead forecast errors for total revenues observed over the last ten years ${ }^{1}$ are graphically depicted in Figure 1, where each point represents a single forecast error. Note that the forecasts are arranged in this figure in descending order of the respective standard deviation of the forecast error. At first sight the figure seems to suggest that in most cases there is some underestimation going on. But there are also instances of large overestimations.

Table 1 provides the corresponding figures for the mean forecast error and its standard deviation. A positive sign indicates an overestimation of revenues, a negative sign an underestimation. In all cases, except for Germany, Japan, and the CBO forecast in the United States, there is a slight underestimation of revenues. The largest mean is found for the Canadian forecast which shows an underestimation of $4.4 \%$ on average. However, given the large standard deviations this is the only case where the mean shows a statistically significant difference from zero at reasonable levels of significance.

As a measure of the precision of forecasts we rely on the standard deviation of the forecast error.

\footnotetext{
1 In the case of Italy there are just nine years, in the case of France eight years, and for the Netherlands due to structural breaks just five out of the last seven years considered.
} 
Figure 1: Forecast Errors

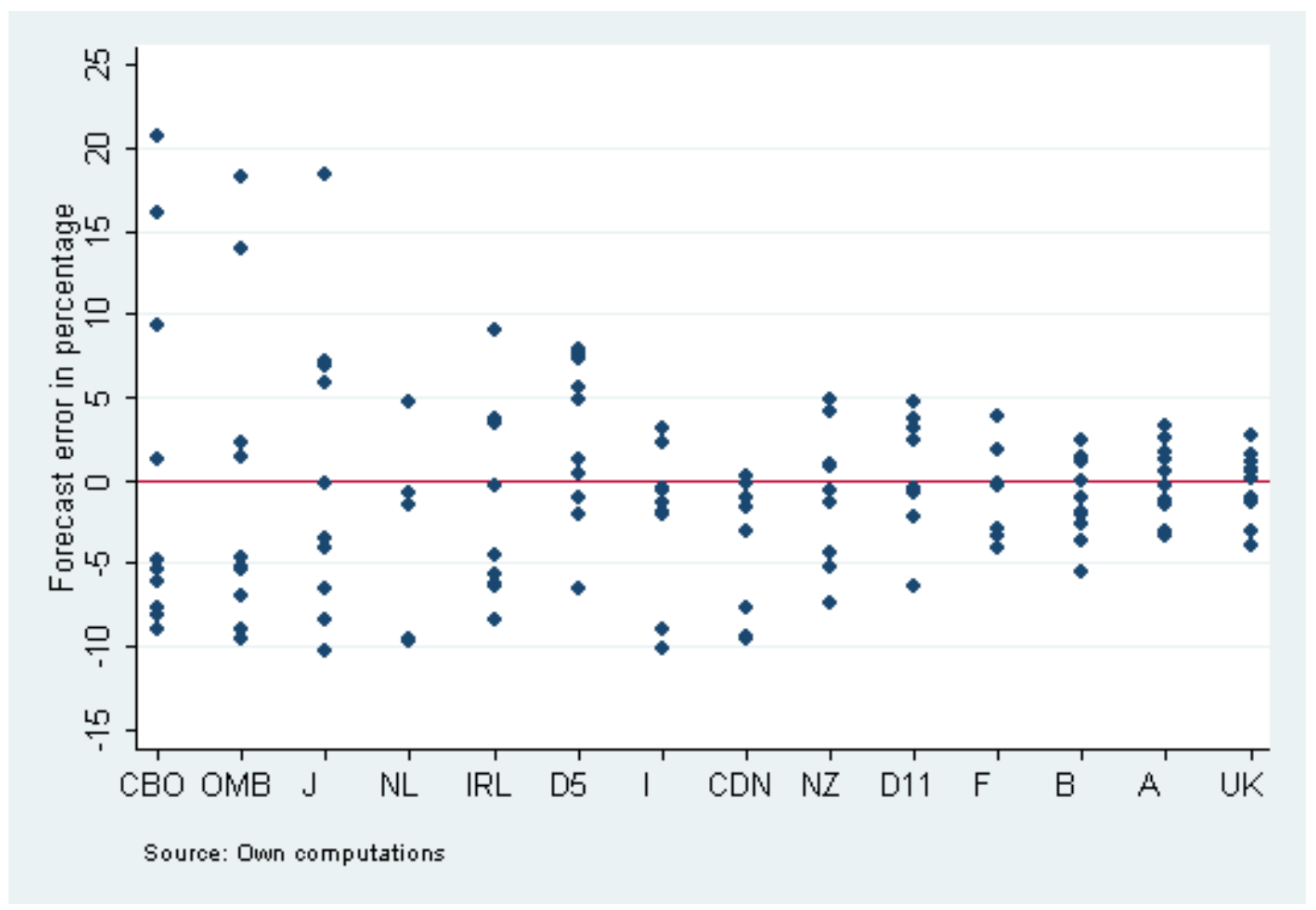

CBO: US Congressional Budet Office, OMB: US Office of Management and Budget, J: Japan, NL: Netherlands, IRL: Ireland, D5: Germany May Forecast, I: Italy, CDN: Canada, NZ: New Zealand, D11: Germany November Forecast, F: France, B: Belgium, A: Austria, UK: United Kingdom.

Figure displays the one-year-ahead forecast errors for total tax revenues in percentage for up to ten years in each country, each point representing one forecast. A positive (negative) value denotes overestimation (underestimation). The forecasts are arranged in descending order of the standard deviation of the respective forecast errors. The two US forecasts only refer to federal taxes. 
Table 1: Descriptive Statistics of Forecast Errors

\begin{tabular}{l|rrr}
\hline \hline Country & \multicolumn{1}{|c}{$\begin{array}{c}\text { Mean } \\
(1)\end{array}$} & $\begin{array}{c}\text { Std.dev. } \\
(2)\end{array}$ & $\begin{array}{c}\text { Obs. } \\
(3)\end{array}$ \\
\hline Austria & -0.037 & 2.279 & 10 \\
Belgium & -1.193 & 2.478 & 10 \\
Canada & -4.363 & 4.163 & 10 \\
France & -1.025 & 2.808 & 8 \\
Germany: May & 2.496 & 4.859 & 10 \\
Germany: Nov & 0.498 & 3.485 & 10 \\
Ireland & -2.133 & 5.759 & 10 \\
Italy & -2.249 & 4.538 & 9 \\
Japan & 0.516 & 8.911 & 10 \\
Netherlands & -3.403 & 6.203 & 5 \\
New Zealand & -1.291 & 4.063 & 10 \\
United Kingdom & -0.286 & 2.069 & 10 \\
USA: CBO & 0.609 & 10.879 & 10 \\
USA: OMB & -0.522 & 9.613 & 10 \\
\hline Average & -0.777 & 5.812 & 132 \\
\hline \multicolumn{3}{|c}{}
\end{tabular}

The first column shows the mean of the one-year-ahead forecast error for total revenues in percentage. A positive (negative) value denotes overestimation (underestimation). The second column depicts the standard deviation of the forecast error in percentage. The last column reports the number of observations. 
The most precise forecast would then show the smallest standard deviation of the forecast error. Taking into account that in most cases no significant bias is found, this forecast would also be the most efficient one. As can be seen in Column (2) of Table 1 the highest precision is achieved in the United Kingdom and Austria, while we find the lowest precision in the United States and Japan.

\section{Conditions Faced by Forecasters}

An assessment of the considerable differences in the precision of forecasts needs to take account of the different conditions faced by the forecaster. First of all this is an issue of the point of time when the forecast is made. This can be illustrated by the two German forecasts that take place in May and November while the budget period starts in January. The standard deviation decreases in the latter by about a quarter presumably due to the decreasing degree of uncertainty, which is naturally lower in November than in March. But also across countries there are important differences in the time span between the forecast and the beginning of the forecasted period (see Column (1) of Table 2). Actually, this time span varies between less than one and 9.5 months.

A second important difference lies in the tax structure of the countries. In particular, the degree of differentiation of the tax system might matter. Rather than relying on few large taxes a country might employ a variety of smaller tax instruments and, thereby, reduce the revenue risks associated with the tax system. Therefore, forecasting the revenues of a large variety of small taxes might be easier than predicting the revenues in a system that relies on a small number of large taxes. To capture the differentiation of the tax structure we use an indicator of the number of taxes. For the calculation we rely on the OECD Revenue Statistics. More specifically, we employ the most 
Table 2: Forecasting Conditions

\begin{tabular}{l|rr}
\hline Country & $\begin{array}{r}\text { Time Span } \\
(1)\end{array}$ & $\begin{array}{c}\text { No. of Taxes } \\
(2)\end{array}$ \\
\hline Austria & 3.5 & 71 \\
Belgium & 2.5 & 58 \\
Canada & 1.5 & 37 \\
France & 3 & 106 \\
Germany: May & 7.5 & 40 \\
Germany: Nov & 1.5 & 23 \\
Ireland & 0.5 & 50 \\
Italy & 6 & 40 \\
Japan & 3.5 & 43 \\
Netherlands & 9.5 & 23 \\
New Zealand & 1.5 & 43 \\
United Kingdom & 0 & 26 \\
US: CBO & 8.5 & 45 \\
US: OMB & 8 & \\
\hline Average & 4.1 & \\
\hline
\end{tabular}

The time span in the first column measures the period between the forecast and the beginning of the forecasted period in months. In the second column the number of taxes existing in the respective country is shown based on the OECD Revenue Statistics. 
detailed classification of taxes and count all items with positive revenues. This is, of course, just an approximation, as the OECD classification meets the various tax systems to a different extent. However, as documented in Column (2) there are large differences across countries/forecasts.

Some taxes might be more difficult to predict than others. For instance, we might expect that there are significant differences in the precision when forecasting corporation or income taxes as compared to sales and value added taxes. This calls for a separate analysis of forecast errors according to the type of tax considered (see below).

\section{Forecasting Methodology}

The forecasting methodology used by the fourteen regular revenue forecasts that are surveyed in this paper shows several similarities. In all countries, the forecasts are prepared in a disaggregated fashion for a number of single taxes, whereby often individual taxes are aggregated into groups especially if they share the same source or tax payer. This partly reflects the need to employ up-to-date information on current revenues, which is available usually only on a cash basis.

A typical feature of revenue forecasting is that taxes which are strongly driven by macroeconomic developments such as corporation taxes or wage and income taxes are forecasted with indirect methods. In these cases revenue estimation relies on information about macroeconomic variables such as GDP, or components of the national accounts, like income from entrepreneurial activity and capital or the wage bill. Predominantly, the elasticity method is employed where some previously estimated elasticity is used to predict revenue growth based on the predicted development of 
the macroeconomic indicators. Some forecasts (United Kingdom, Netherlands, New Zealand, and Japan) reportedly make use of econometric models where the relationship between revenues and economic indicators is directly estimated using regression analysis.

In some cases the use of micro-simulation methods is reported which are focusing on individual tax payers such as households or corporations and where the accrued taxes for each individual are calculated and aggregated afterwards. This approach is used in the Netherlands and the United States in forecasting income taxes, in the United Kingdom and the United States for predicting corporation tax revenues.

While the macroeconomic forecasts are used as exogenous variables in countries such as Germany and Belgium, repercussions of revenue forecasts on the macroeconomic forecast over the budget are taken into account in some other countries. In particular, revenue forecasts that are embedded in a macroeconomic model (United Kingdom and Netherlands) produce a consistent set of macroeconomic and revenue forecasts. Other countries such as Ireland, New Zealand, and the United States $(\mathrm{CBO})$ report the mutual verification and acknowledgement of macroeconomic and revenue forecasts.

For less important taxes - in terms of revenues - like excise taxes, but also for taxes with just a weak relation to macroeconomic variables usually direct methods are employed. These methods, like trend-extrapolation or more formal time-series analysis, use revenue data of the respective tax from previous years to predict the expected development. Also the usage of vector-autoregressive methods for groups of taxes is reported.

A subtle issue for revenue forecasting is how to deal with changes in the tax law, in particular, 
if changes are planned but have not yet been enacted as a law. In some countries, it is common practice to include changes that are agreed within the government (Austria, Netherlands) or noted in the budget plan (Ireland). Even if tax law changes that are just planned are not directly taken into account in the forecast, their expected macroeconomic impact sometimes leads to an indirect influence on the forecast.

\section{$5 \quad$ Institutions and Independence}

A basic institutional aspect of revenue forecasting is the assignment of the forecasting task to specific institutions. Interestingly, forecasting is not always assigned to a department of the government or, more precisely, to the executive branch of the government. Only in about half of the fourteen forecasts surveyed in this paper it is the Ministry of Finance (Belgium, France, Italy, Ireland, Japan) or the Treasury (United Kingdom, New Zealand) that is responsible. In most other cases forecasting is assigned to a group representing different institutions, not only from the government. Some countries even assign the primary responsibility for revenue forecasting to independent research institutes (Netherlands) and limit the influence of government to merely consult forecasters. In the other countries, even if the Ministry of Finance or another part of the government is responsible, often external experts from academia or forecasting agencies are included in the forecasting group.

The efforts to involve institutions that are not part of the government or other external experts are usually justified as a means to raise the independence of the revenue forecasting from possible manipulation and strategic influences by the government. Several countries explicitly produce consensus forecasts, where all institutions and experts involved have to agree on the forecast (e.g., 
Germany and Austria). However, the extent to which forecasting is independent from government manipulation is not only depending on the assignment of the forecasting responsibility but also on whether revenue forecasting is based on some official predictions for the macroeconomic development, as is the case with the German forecast.

Table 3 presents information about how revenue forecasting differs with respect to these issues. The first column indicates whether the government $(=0)$, research institutes $(=1)$ or both jointly $(=0.5)$ are responsible for the forecast. In some cases there are no research institutes involved, but in order to preserve a certain degree of independence there are external experts consulted (see Column (2)). This is the case for the US forecasts of the Congressional Budget Office (CBO) and the Office of Management and Budget (OMB). In the case of the United Kingdom a value of 0.5 is entered, in order to take account of the reported partial consultation of experts. Also for Germany a figure 0.5 is entered in order to account for the additional participation of the German central bank. For the Netherlands a figure of -1 is entered to take account of the consulting participation of the ministry of finance that may tend to reduce independence. Even if the revenue forecast is done with collaboration of the government, in some countries an external, non-government macroeconomic forecast is used. Therefore, the third column provides information about the source of the macroeconomic forecast. A value of one indicates that an external forecast is used.

By summing across the first three columns we obtain a simple indicator of the independence of revenue forecasting. The first column is weighted with unity, the second and the third columns are weighted with 0.25 . The rational behind this weighting is the following: a revenue forecast that is conducted by a research institute without any government experts involved would display the maximum level of independence $(=1)$. A government forecast that includes external experts and 
employs an external macroeconomic forecast would obtain a medium level of independence $(=0.5)$.

A government forecast without any external experts and without an external macroeconomic forecast would be assigned the lowest level of independence $(=0)$.

While the indicator varies from zero (=no independence) to unity (=full independence), in our sample of countries the highest degree of independence is 0.75. As can be seen, the indicator is highest for the Netherlands and Austria, followed by Germany. A small, but positive level of independence can be found in Canada, New Zealand, Belgium and the United Kingdom. The United States case is somewhat special since here two separate forecasts exist. One is conducted by the Office of Management and Budget (OMB) that assists the executive branch, the other is conducted by the Congressional Budget Office (CBO) that is assigned to the legislative branch. While their incentives to strategically manipulate forecasts might differ, our indicator of independence, which is simply assessing the institutional conditions, assigns a low value of independence to both of them. ${ }^{2}$

The general composition of the index with its emphasis on research institutes, external experts, and the source of the macroeconomic forecast reflects the main institutional characteristics of revenue forecasting. Yet the weights, used to aggregate the information about these institutional aspects, are somewhat arbitrary. Therefore, we conducted some robustness checks where the weights for external experts and external macroeconomic forecasts were increased or lowered. With regard to the ranking, however, only minor changes were found. We will come back to this issue below, where we explore whether the index of independence has sufficient informational content in order to help explaining the observed performance.

\footnotetext{
${ }^{2}$ Bretschneider et al. (1989) argue that the existence of two separate forecasts by the legislative and the executive branch exerts a positive effect on forecasting accuracy, in particular, when both forecasts are forced into a consensus. This is, however, not the case with the OMB and CBO.
} 
Table 3: Institutional Characteristics and Independence

\begin{tabular}{l|rrrr}
\hline Country & $\begin{array}{r}\text { Research } \\
\text { institutes }\end{array}$ & $\begin{array}{r}\text { Ext./Gov. } \\
\text { experts }\end{array}$ & $\begin{array}{r}\text { Macroecon. } \\
\text { forecast }\end{array}$ & $\begin{array}{r}\text { Indepen- } \\
\text { dence }\end{array}$ \\
\hline Netherlands & 1 & -1 & 0 & 0.75 \\
Austria & .5 & 0 & 1 & 0.75 \\
Germany: May & .5 & .5 & 0 & 0.625 \\
Germany: Nov & .5 & .5 & 0 & 0.625 \\
USA: OMB & 0 & 1 & 0 & 0.25 \\
USA: CBO & 0 & 1 & 0 & 0.25 \\
Canada & 0 & 0 & 1 & 0.25 \\
New Zealand & 0 & 1 & 0 & 0.25 \\
Belgium & 0 & 0 & 1 & 0.25 \\
United Kingdom & 0 & .5 & 0 & 0.125 \\
Japan & 0 & 0 & 0 & 0.00 \\
France & 0 & 0 & 0 & 0.00 \\
Italy & 0 & 0 & 0 & 0.00 \\
Ireland & 0 & 0 & 0 & 0.00 \\
\hline
\end{tabular}

First column indicates whether the government $(=0)$, research institutes $(=1)$ or both jointly are responsible for the forecast $(=0.5)$. Second column indicates whether external $(=1)$ or government experts $(=-1)$ are involved. For the United Kingdom a value of 0.5 is entered, in order to take account of the reported partial consultation of experts. In Germany a figure 0.5 is entered in order to account for the participation of the central bank. Third column provides information about whether an external, non-government macroeconomic forecast is used. The degree of independence in the last column is obtained as a weighted sum of the first three columns. The first column is weighted with unity, the second and the third columns are weighted with 0.25 (see text). 


\section{Determinants of Forecasting Performance}

Having outlined differences in forecasting conditions and practices let us finally turn to the question as to what extent they are associated with the large differences in forecasting performance noted above. Since in most cases the mean forecast error does not point at significant biases, we focus on the precision of forecasting as documented by the standard deviation of forecast errors. More specifically, we analyze the precision of the forecasts for total revenues as well as for revenues grouped using a broad classification of the sources of taxation.

The first two regressions in Table 4 explore whether differences in forecasting conditions show some significant relation with the standard deviation of the forecast error for total tax revenues. Column (1) just includes the time span between the forecast and forecasted period and indicates that the uncertainty increases considerably with the time span: every additional month increases the standard deviation by a half percentage point. In Column (2) we have included the number of individual taxes as a measure of the differentiation of the tax system. Accordingly, forecasting is more accurate in countries where the number of taxes is large. The coefficient of determination indicates that about two thirds of the variation in the forecasting accuracy are associated with differences in the time span and the number of taxes involved.

Columns (3) and (4) show the same specifications augmented with our indicator of independence of revenue forecasting. While the results from Columns (1) and (2) are confirmed, we find that the precision of the forecast is positively associated with independence. As the indicator of independence rests on a weighted sum of three institutional characteristics we conducted some robustness tests using different weights. However, the results do not show major differences. If the weights for 


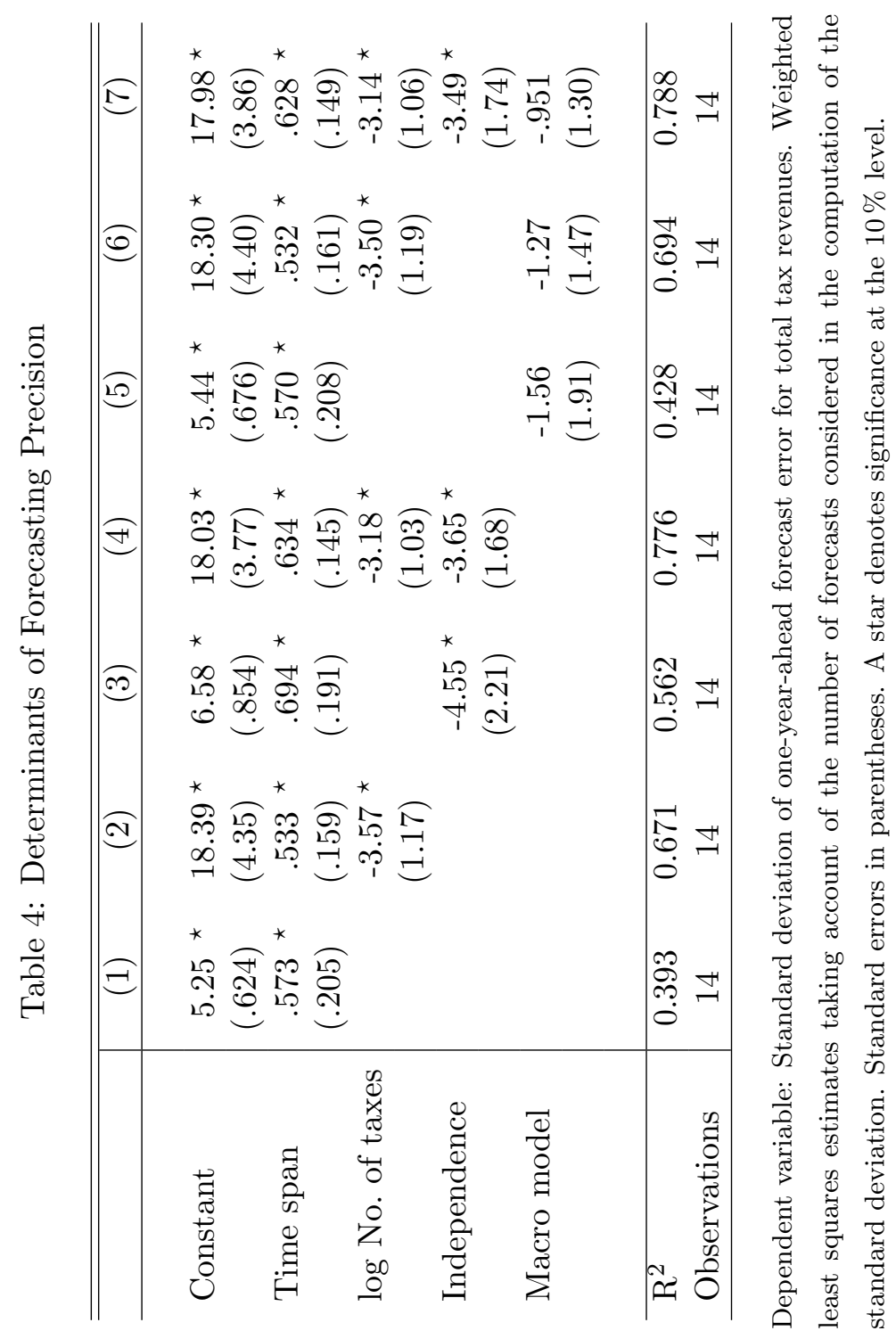


external experts or external macroeconomic forecasts are increased or lowered by 0.1 , for instance, all effects are confirmed while the coefficient of determination is slightly lower with these alternative weights. The specification in Column (4) indicates that about three fourth of the variation in the precision can be attributed to the time span, the number of taxes involved, and the degree of independence.

The results presented in Columns (5) to (7) indicate that embedding revenue forecasts into a macroeconomic model is associated with a higher precision. However, this effect is not significant. In further experiments (not shown) we tested for an association with the country size but did not find any significance.

Table 5 provides results for the precision of forecasts decomposed into four different types of taxes: (personal) income taxes, corporation taxes, sales taxes and other taxes. Thus, for each group of taxes we compute a separate standard deviation of the forecast error. ${ }^{3}$ A first specification uses a similar set of variables as Column (4) of Table 4. In addition, it includes dummy variables for each group of taxes. The coefficients of these variables point at strong differences in forecasting accuracy: income taxes and, in particular, corporation taxes show a much larger standard deviation of the forecast error. While the dummy variables point at an important role of the tax structure, the number of taxes in each group does not show a significant effect (see Column 1). However, further inspection revealed that the number of taxes is particularly high among sales and other taxes. Hence, the negative significant effect of the number of taxes obtained in the above analysis of the total forecast error is now picked up by the dummy variables for the groups of taxes. We, therefore, exclude the number of taxes in the subsequent analysis and focus on the dummy vari-

\footnotetext{
${ }^{3}$ Missing values are encountered since detailed information was not available for all countries.
} 
Table 5: Determinants of Forecasting Precision by Type of Tax

\begin{tabular}{|c|c|c|c|c|c|}
\hline & (1) & $(2)$ & $(3)$ & (4) & $(5)$ \\
\hline Time span & $\begin{array}{l}.868 \text { * } \\
(.241)\end{array}$ & $\begin{array}{l}.860 \text { * } \\
(.240)\end{array}$ & $\begin{array}{l}.636 \text { * } \\
(.243)\end{array}$ & $\begin{array}{l}-.037 \\
(.253)\end{array}$ & $\begin{array}{l}-.050 \\
(.235)\end{array}$ \\
\hline Time span $\times$ Tax type 1 & & & & $\begin{array}{l}.550 \\
(.332)\end{array}$ & $\begin{array}{l}.405 \\
(.324)\end{array}$ \\
\hline Time span $\times$ Tax type 2 & & & & $\begin{array}{l}2.06 \\
(.354)\end{array}$ & $\begin{array}{l}2.06 \text { * } \\
(.278)\end{array}$ \\
\hline Time span $\times$ Tax type 3 & & & & $\begin{array}{l}.286 \\
(.314)\end{array}$ & $\begin{array}{c}.286 \\
(.287)\end{array}$ \\
\hline Micro-simulation & & & $\begin{array}{l}6.17 \text { * } \\
(2.99)\end{array}$ & $\begin{array}{l}6.63 \\
(1.39)\end{array}$ & $\begin{array}{l}7.71 \text { * } \\
(1.06)\end{array}$ \\
\hline Independence & $\begin{array}{l}-4.76 \text { * } \\
(1.89)\end{array}$ & $\begin{array}{l}-4.60 \text { * } \\
(1.79)\end{array}$ & $\begin{array}{l}-3.25^{\star} \\
(1.63)\end{array}$ & $\begin{array}{l}-3.25 \star \\
(1.31)\end{array}$ & $\begin{array}{l}-2.86 \text { * } \\
(1.32)\end{array}$ \\
\hline Macro model & & & $\begin{array}{l}-2.26{ }^{\star} \\
(1.34)\end{array}$ & $\begin{array}{l}-2.35^{\star} \\
(1.10)\end{array}$ & $\begin{array}{l}-.612 \\
(2.56)\end{array}$ \\
\hline Macro model $\times$ Tax type 1 & & & & & $\begin{array}{l}-2.61 \\
(3.40)\end{array}$ \\
\hline Macro model $\times$ Tax type 2 & & & & & $\begin{array}{l}-5.80 \text { * } \\
(2.74)\end{array}$ \\
\hline Macro model $\times$ Tax type 3 & & & & & $\begin{array}{c}.271 \\
(2.87)\end{array}$ \\
\hline log No. of taxes by category & $\begin{array}{c}.351 \\
(.945)\end{array}$ & & & & \\
\hline Tax type 1 (Income taxes) & $\begin{array}{l}7.54 \text { * } \\
(1.48)\end{array}$ & $\begin{array}{l}7.94 \\
(1.19)\end{array}$ & $\begin{array}{l}6.48 \text { * } \\
(1.21)\end{array}$ & $\begin{array}{l}6.43 \text { ^ } \\
(.974)\end{array}$ & $\begin{array}{c}6.12 \text { * } \\
(1.03)\end{array}$ \\
\hline Tax type 2 (Corporation taxes) & $\begin{array}{l}15.44 \text { * } \\
(1.88)\end{array}$ & $\begin{array}{l}15.77^{\star} \\
(1.95)\end{array}$ & $\begin{array}{l}14.56 \text { * } \\
(1.85)\end{array}$ & $\begin{array}{l}14.88 \text { * } \\
(1.09)\end{array}$ & $\begin{array}{l}15.17 \text { * } \\
(1.09)\end{array}$ \\
\hline Tax type 3 (Sales taxes) & $\begin{array}{c}4.93 \\
(3.03)\end{array}$ & $\begin{array}{l}5.97 \text { } \\
(.989)\end{array}$ & $\begin{array}{l}5.83 \text { * } \\
(.927)\end{array}$ & $\begin{array}{l}5.80 \text { * } \\
(.754)\end{array}$ & $\begin{array}{l}5.41 \text { * } \\
(.772)\end{array}$ \\
\hline Tax type 4 (Others) & $\begin{array}{l}5.19 \\
(2.58)\end{array}$ & $\begin{array}{l}5.88 \\
(1.36)\end{array}$ & $\begin{array}{l}5.74 \\
(1.27)\end{array}$ & $\begin{array}{l}5.68 \\
(.857)\end{array}$ & $\begin{array}{l}5.33 \text { * } \\
(.893)\end{array}$ \\
\hline $\mathrm{R}^{2}$ & 0.849 & 0.849 & 0.879 & 0.944 & 0.952 \\
\hline Observations & 50 & 50 & 50 & 50 & 50 \\
\hline
\end{tabular}

Dependent variable: Standard deviation of forecast error for tax revenues grouped into four types of taxes. Weighted least squares estimates taking account of the number of forecasts considered in the computation of the standard deviation. Robust standard errors in parentheses. An asterisk indicates significance at the $10 \%$ level. 
ables for the types of taxes. As documented by the coefficient of determination in Column (2), nevertheless, about $85 \%$ of the differences in the precision can be assigned to tax structure, timing, and independence.

Column (3) includes controls for micro-simulation models used in the respective group and for embedding the revenue forecast into a macroeconomic model. While the integration of revenue forecasting into a macroeconomic model is found to improve the quality of the forecast, microsimulations seem to be associated with a reduced precision. However, the latter finding might well reflect a selection effect, since micro-simulation methods might be implemented for those taxes where the forecaster faces a substantial complexity.

In the fourth specification we control for possible differences in the effect of the timing among the different groups of taxes. As can be seen, the time span is relevant, particularly for corporation taxes, but also for income taxes. Probably, the precision of the GDP forecast is very important for these taxes; and this precision is very likely to decrease with the time span. In Column (5) also the effect of embedding the forecast into a macroeconomic model is allowed to differ between the various groups of taxes. Since the standard deviation of the forecast error is significantly lower, macroeconomic models are found to be particularly helpful in predicting corporation taxes. This points at the importance of macroeconomic repercussions for those taxes. 


\section{Conclusions}

In this paper we have compared revenue forecasting practice and performance across selected OECD countries. While the mean one-year-ahead forecast error is small in most countries, the precision of the forecasts measured by the standard deviation of the forecast error differs substantially across countries. This raises the question of whether differences in the performance are associated with the practice of revenue forecasting in these countries.

A consideration of methodological aspects shows fairly similar approaches among all countries. Taxes being sensitive to the business cycle (such as income and corporation taxes) are mainly forecasted with indirect methods that are based on macroeconomic indicators. For other taxes, direct methods are employed, where the forecast is a function of the revenues from previous years. Methodological differences are found with regard to macroeconomic models and micro-simulation models. In some countries revenue forecasts are directly embedded in a macroeconomic model, where budgetary repercussions are directly taken into account. Micro-simulations are used in some countries to predict revenues for specific taxes such as income taxes.

Institutional arrangements vary between countries. While in some countries the ministry of finance or the treasury is responsible, other countries assign the forecasting task to research institutes. Further differences arise with regard to the inclusion of external experts and with regard to the source of macroeconomic forecasts. To summarize these differences we come up with an index of the independence from possible government manipulation. According to this index the revenue forecasts are most independent in the Netherlands and in Austria. 
The quantitative analysis shows that the cross-country differences in the performance of revenue forecasting are to some extent driven by country characteristics such as the tax structure with regard to the number of taxes and the importance of income and corporation taxes. Also differences in the timing of the forecasts prove important. Controlling for these differences we also find that the precision of revenue forecasting increases with the independence of forecasts. About three quarters of the differences in accuracy concerning the total revenues can be explained by differences in the tax structure, the time span, and the degree of independence.

These results are confirmed when distinguishing between four groups of taxes, i.e. income taxes, corporation taxes, sales taxes, and a residual category. This analysis further shows that the forecasting accuracy is particularly low for corporation taxes. For these taxes we find that the precision depends strongly on the time-span between the forecast and the beginning of the forecasted period. With regard to methods, we see that the precision turns out to be rather low where micro-simulation methods are applied. Embedding the forecast in a macroeconomic model, however, is associated with a lower standard deviation of the forecast error in particular for the corporation taxes.

\section{Appendix: Sources of Information}

\section{A.1 Austria}

The revenue forecast for Austria is documented/discussed in:

- Bundesministerium für Finanzen (2007): Budget 2007-2008, Zahlen - Hintergründe - Zusammenhänge. Online: www.bmf.gv.at

- Homepage of the Ministry of Finance: www.bmf.gv.at

- Homepage of the Wifo (Österreichisches Institut für Wirtschaftsforschung): www.wifo.ac.at 
- Leibrecht (2004)

\section{A.2 Belgium}

The revenue forecast of the federal government is documented/discussed in:

- Chambre des représentants de Belgique: Budgets des Recettes et des Dépenses pour l'année budgétaire 1996, ... pour l'année budgétaire 2007, Brussels

- Hertveldt, Bart et al. (2003)

- Lenoir, Thierry und Valenduc, Christian (2006): Révision de la méthode macro-économique d'estimation des recettes fiscales. Service Public Fédéral Finances, Brussels

\section{A.3 Canada}

The spring revenue forecast of the Canadian Department of Finance is documented/discussed in:

- Mühleisen et al. (2005)

- O'Neill, Tim (2005): Review of Canadian Federal Fiscal Forecasting: Processes and Systems. O'Neill Strategic Economics. Online: www.fin.gc.ca/toce/2005/oneil_e.html

- Homepage of the Department of Finance Canada: www.fin.gc.ca

\section{A.4 France}

The revenue forecast of the French government is documented/discussed in:

- Homepage of the Juridictions financières: www.ccomptes.fr

- Homepage of the Ministère des Finances: www.minefi.gouv.fr

- Homepage of the Ministère du Budget, des Comptes Publics et de la fonction publique: www.budget.gouv.fr

- Les déterminants des ressources de l'État: www.vie-publique.fr 


\section{A.5 Germany}

The centralized forecast of the consensus forecasting group is documented/discussed in:

- Bundesministerium der Finanzen: Finanzbericht 1997-2008

- Bundesministerium der Finanzen (2005): 50 Jahre Arbeitskreis "Steuerschätzung"

- Gebhardt (2001)

- Homepage of the Ministry of Finance: www.bundesfinanzministerium.de

\section{A.6 Ireland}

The revenue forecast of the Irish Government is documented/discussed in:

- Budgets of the Department of Finance: www.budget.gov.ie

- Homepage of the Ministry of Finance: www.finance.gov.ie

- Homepage of the Revenue Commissioners: www.revenue.ie

- Minutes of the "Committee of Public Accounts" of the Irish Parliament on 23. January 2003: www.irlgov.ie/committees-29/c-publicaccounts/20030123/Page1.htm

- Report of the Tax Forecasting Methodology Review Group, 2008: www.finance.gov.ie

- The Tax Forecasting Methodology Group, 1999: www.finance.gov.ie

\section{A.7 Italy}

The revenue forecast of the Italian government is documented/discussed in:

- Ministero dell'Economia e delle Finanze, Rome: Documento di Programmazione Economico e Finanziaria per gli anni 1998-2000, ... per gli anni 2006-2009

- Istituto Nazionale di Statistica (2007), Rome: Conti e aggregati economici delle Amministrazioni pubbliche. Statistiche in breve, anni 1980-2006 


\section{A.8 Japan}

The revenue forecast of the Japanese government is documented/discussed in:

- Adachi (2006), (in Japanese), PRI Discussion Paper Series, No. 06A-07

- Homepage of the Cabinett Office: www.cao.go.jp

- Homepage of the Ministry of Finance: www.mof.go.jp

\section{A.9 Netherlands}

The revenue forecast of the CPB is documented/discussed in:

- $\operatorname{Bos}(2007)$.

- CPB Netherlands Bureau for Economic Policy Analysis (2005): Forecasting Tax Revenue. CPB Presentation

- European Commission (2006): European Economy No 3 / 2006, Public finances in EMU 2006

- Homepage of the CPB Netherlands Bureau for Economic Policy Analysis: www.cpb.nl

- Ministry of Finance (2007): Stability Programme of the Netherlands, November 2007 Update: http://ec.europa.eu/economy_finance/about/activities/sgp/ country/countryfiles/dec_2007/nl_2007_en.pdf

- Teulings, Coen (2006): Forecasting, Policy Evaluation and the Budgetary Process. Lessons from the Netherlands. CPB Presentation

\section{A.10 New Zealand}

The revenue forecast of the Treasury is documented/discussed in:

- Homepage of the Treasury: www.treasury.govt.nz

- Keene and Thomson (2007)

- New Zealand Treasury (2002): Treasury's Forecasting Process. Presentation Online: www.treasury.govt.nz

- New Zealand Treasury (2007): Budget Economic and Fiscal Update 2007. Online: www.treasury.govt.nz 


\section{A.11 United Kingdom}

The revenue forecast of the Treasury is documented/discussed in:

- HM Treasury (2007a): Budget 2007, HM Treasury, London

- HM Treasury (2007b): Meeting the aspirations of the British people: 2007 Pre-Budget Report and Comprehensive Spending Review, HM Treasury, London

- Homepage of the Treasury: www.hm-treasury.gov.uk

- Pike, Tim und Savage, David (1998): Forecasting the Public Finances in the Treasury. Fiscal Studies 19(1), 49-62

\section{A.12 USA}

The forecasts for federal revenues by the Congressional Budget Office and the Office of Management and Budget are documented/discussed in:

- Auerbach (1999).

- Congressional Budget Office (1995): Budget Estimates: Current Practices and Alternative Approaches. CBO Papers Series, Washington D.C.

- Congressional Budget Office (1998): Projecting Federal Tax Revenues and the Effect of Changes in Tax Law Memorandum, Washington D.C.

- Congressional Budget Office (2006): CBO's Policies for Preparing and Distributing Its Estimates and Analyses, Washington D.C.

- Congressional Budget Office (2007): The Uncertainty of Budget Projections: A Discussion of Data and Methods. Memorandum, Washington D.C.

- Homepage of the Congressional Budget Office (CBO): www.cbo.gov

- Homepage of the Office of Management and Budget (OMB): www.whitehouse.gov/omb

- Joint Committee on Taxation (JCT) (1992): Discussion of Revenue Estimation Methodology and Process. US Government Printing Office, Washington D.C.

\section{References}

Auerbach, Alan J. (1999): On the Performance and Use of Government Revenue Forecasts. National Tax Journal, 52 (4), S. 765-782. 
Bos, Frits (2007): The Dutch fiscal framework. History, current practice and the role of the CPB. Online: www.cpb.nl/nl/pub/cpbreeksen/document/150/doc150.pdf.

Bretschneider, S. I., Gorr, W. L., Grizzle, G. and Klay, E. (1989): Political and organizational influences on the accuracy of forecasting state government revenues, International Journal of Forecasting 5 (1989), 307-319.

Boylan, R. T., 2008, Political Distortions in State Forecasts, Public Choice 136, 411-427.

Danninger, S., 2005, Revenue Forecasts as Performance Targets, IMF Working Papers 05/14.

Feenberg, Daniel R., William Gentry, David Gilroy, Harvey S. Rosen (1989): Testing the Rationality of State Revenue Forecasts, Review of Economics and Statistics 71 (2), 300-308.

Gebhardt, Heinz (2001): Methoden, Probleme und Ergebnisse der Steuerschätzung, RWI-Mitteilungen 2001, 127-147.

Hertveldt, Bart et al. (2003): Tout savoir sur la confection du budget économique. Federal Planning Bureau Working Paper, Brussels.

Keene, Martin und Peter Thomson (2007): An Analysis of Tax Revenue Forecast Errors, Working Paper 07/02, New Zealand Treasury, Wellington.

Krause, George A., David E. Lewis, James W. Douglas (2006): Political Appointments, Civil Service Systems, and Bureaucratic Competence: Organizational Balancing and Executive Branch Revenue Forecasts in the American States, American Journal of Political Science 50, 770-787.

Jonung, L. and Larch, M. (2006): Improving fiscal policy in the EU: the case for independent forecasts, Economic Policy 21, 491-534.

Kyobe, Annette, and Stephan Danninger, 2005. Revenue Forecasting-How is it done? Results from a Survey of Low-Income Countries. IMF Working Papers 05/24.

Leal, T., Perez, J.J., Tujula, M., and J. Vidal, 2008, Fiscal Forecasting: Lessons from the Literature and Challenges Fiscal Studies 29 (3), 347-386.

Leibrecht, Markus (2004): Steuerschätzung in Österreich: Ablauf, Methoden und Präzision der Prognose, Deutscher Universitätsverlag, Wiesbaden.

Lenoir, Thierry und Valenduc, Christian (2006): Révision de la méthode macro-économique d'estimation des recettes fiscales, Brussels.

Mühleisen, Martin, Stephan Danninger, David Hauner, Kornélia Krajnyák, Bennett Sutton (2005): How Do Canadian Budget Forecasts Compare with Those of Other Industrial Countries? IMF Working Paper, WP/05/66.

Pike, Tim und Savage, David (1998): Forecasting the Public Finances in the Treasury. Fiscal Studies 19(1), 49-62. 


\section{CESifo Working Paper Series}

for full list see www.cesifo-group.org/wp

(address: Poschingerstr. 5, 81679 Munich, Germany, office@cesifo.de)

2565 Patricia Apps, Ngo Van Long and Ray Rees, Optimal Piecewise Linear Income Taxation, February 2009

2566 John Whalley and Shunming Zhang, On the Arbitrariness of Consumption, February 2009

2567 Marie-Louise Leroux, Endogenous Differential Mortality, Non-Contractible Effort and Non Linear Taxation, March 2009

2568 Joanna Bęza-Bojanowska and Ronald MacDonald, The Behavioural Zloty/Euro Equilibrium Exchange Rate, March 2009

2569 Bart Cockx and Matteo Picchio, Are Short-Lived Jobs Stepping Stones to Long-Lasting Jobs?, March 2009

2570 David Card, Jochen Kluve and Andrea Weber, Active Labor Market Policy Evaluations: A Meta-analysis, March 2009

2571 Frederick van der Ploeg and Anthony J. Venables, Harnessing Windfall Revenues: Optimal Policies for Resource-Rich Developing Economies, March 2009

2572 Ondřej Schneider, Reforming Pensions in Europe: Economic Fundamentals and Political Factors, March 2009

2573 Jo Thori Lind, Karl Ove Moene and Fredrik Willumsen, Opium for the Masses? Conflict-Induced Narcotics Production in Afghanistan, March 2009

2574 Silvia Marchesi, Laura Sabani and Axel Dreher, Agency and Communication in IMF Conditional Lending: Theory and Empirical Evidence, March 2009

2575 Carlo Altavilla and Matteo Ciccarelli, The Effects of Monetary Policy on Unemployment Dynamics under Model Uncertainty - Evidence from the US and the Euro Area, March 2009

2576 Falko Fecht, Kjell G. Nyborg and Jörg Rocholl, The Price of Liquidity: Bank Characteristics and Market Conditions, March 2009

2577 Giorgio Bellettini and Filippo Taddei, Real Estate Prices and the Importance of Bequest Taxation, March 2009

2578 Annette Bergemann and Regina T. Riphahn, Female Labor Supply and Parental Leave Benefits - The Causal Effect of Paying Higher Transfers for a Shorter Period of Time, March 2009 
2579 Thomas Eichner and Rüdiger Pethig, EU-Type Carbon Emissions Trade and the Distributional Impact of Overlapping Emissions Taxes, March 2009

2580 Antonios Antypas, Guglielmo Maria Caporale, Nikolaos Kourogenis and Nikitas Pittis, Selectivity, Market Timing and the Morningstar Star-Rating System, March 2009

2581 António Afonso and Christophe Rault, Bootstrap Panel Granger-Causality between Government Budget and External Deficits for the EU, March 2009

2582 Bernd Süssmuth, Malte Heyne and Wolfgang Maennig, Induced Civic Pride and Integration, March 2009

2583 Martin Peitz and Markus Reisinger, Indirect Taxation in Vertical Oligopoly, March 2009

2584 Petra M. Geraats, Trends in Monetary Policy Transparency, March 2009

2585 Johannes Abeler, Armin Falk, Lorenz Götte and David Huffman, Reference Points and Effort Provision, March 2009

2586 Wolfram F. Richter, Taxing Education in Ramsey’s Tradition, March 2009

2587 Yin-Wong Cheung, Menzie D. Chinn and Eiji Fujii, China's Current Account and Exchange Rate, March 2009

2588 Alexander Haupt and Silke Uebelmesser, Voting on Labour-Market Integration and Education Policy when Citizens Differ in Mobility and Ability, March 2009

2589 Hans Jarle Kind, Marko Koethenbuerger and Guttorm Schjelderup, Should UtilityReducing Media Advertising be Taxed?, March 2009

2590 Alessandro Cigno, How to Avoid a Pension Crisis: A Question of Intelligent System Design, March 2009

2591 Helmut Lütkepohl and Fang Xu, The Role of the Log Transformation in Forecasting Economic Variables, March 2009

2592 Rainald Borck, Hyun-Ju Koh and Michael Pflüger, Inefficient Lock-in and Subsidy Competition, March 2009

2593 Paolo M. Panteghini, On the Equivalence between Labor and Consumption Taxation, March 2009

2594 Bruno S. Frey, Economists in the PITS?, March 2009

2595 Natalie Chen and Dennis Novy, International Trade Integration: A Disaggregated Approach, March 2009

2596 Frédérique Bec and Christian Gollier, Term Structure and Cyclicity of Value-at-Risk: Consequences for the Solvency Capital Requirement, March 2009 
2597 Carsten Eckel, International Trade and Retailing, March 2009

2598 Gianni De Nicolò and Iryna Ivaschenko, Global Liquidity, Risk Premiums and Growth Opportunities, March 2009

2599 Jay Pil Choi and Heiko Gerlach, International Antitrust Enforcement and Multi-Market Contact, March 2009

2600 Massimo Bordignon and Guido Tabellini, Moderating Political Extremism: Single Round vs Runoff Elections under Plurality Rule, April 2009

2601 Ana B. Ania and Andreas Wagener, The Open Method of Coordination (OMC) as an Evolutionary Learning Process, April 2009

2602 Simon Gächter, Daniele Nosenzo, Elke Renner and Martin Sefton, Sequential versus Simultaneous Contributions to Public Goods: Experimental Evidence, April 2009

2603 Philippe Jehiel and Andrew Lilico, Smoking Today and Stopping Tomorrow: A Limited Foresight Perspective, April 2009

2604 Andreas Knabe, Steffen Rätzel, Ronnie Schöb and Joachim Weimann, Dissatisfied with Life, but Having a Good Day: Time-Use and Well-Being of the Unemployed, April 2009

2605 David Bartolini and Raffaella Santolini, Fiscal Rules and the Opportunistic Behaviour of the Incumbent Politician: Evidence from Italian Municipalities, April 2009

2606 Erkki Koskela and Jan König, Can Profit Sharing Lower Flexible Outsourcing? A Note, April 2009

2607 Michel Beine, Frédéric Docquier and Çağlar Özden, Diasporas, April 2009

2608 Gerd Ronning and Hans Schneeweiss, Panel Regression with Random Noise, April 2009

2609 Adam S. Booij, Bernard M.S. van Praag and Gijs van de Kuilen, A Parametric Analysis of Prospect Theory's Functionals for the General Population, April 2009

2610 Jeffrey R. Brown, Julia Lynn Coronado and Don Fullerton, Is Social Security Part of the Social Safety Net?, April 2009

2611 Ali Bayar and Bram Smeets, Economic, Political and Institutional Determinants of Budget Deficits in the European Union, April 2009

2612 Balázs Égert, The Impact of Monetary and Commodity Fundamentals, Macro News and Central Bank Communication on the Exchange Rate: Evidence from South Africa, April 2009

2613 Michael Melvin, Christian Saborowski, Michael Sager and Mark P. Taylor, Bank of England Interest Rate Announcements and the Foreign Exchange Market, April 2009 
2614 Marie-Louise Leroux, Pierre Pestieau and Gregory Ponthiere, Should we Subsidize Longevity?, April 2009

2615 Ronald MacDonald, Lukas Menkhoff and Rafael R. Rebitzky, Exchange Rate Forecasters' Performance: Evidence of Skill?, April 2009

2616 Frederick van der Ploeg and Steven Poelhekke, The Volatility Curse: Revisiting the Paradox of Plenty, April 2009

2617 Axel Dreher, Peter Nunnenkamp, Hannes Öhler and Johannes Weisser, Acting Autonomously or Mimicking the State and Peers? A Panel Tobit Analysis of Financial Dependence and Aid Allocation by Swiss NGOs, April 2009

2618 Guglielmo Maria Caporale, Roman Matousek and Chris Stewart, Rating Assignments: Lessons from International Banks, April 2009

2619 Paul Belleflamme and Martin Peitz, Asymmetric Information and Overinvestment in Quality, April 2009

2620 Thomas Dohmen, Armin Falk, David Huffman and Uwe Sunde, Are Risk Aversion and Impatience Related to Cognitive Ability?, April 2009

2621 Yin-Wong Cheung and Xingwang Qian, The Empirics of China's Outward Direct Investment, April 2009

2622 Frédérique Bec and Christian Gollier, Assets Returns Volatility and Investment Horizon: The French Case, April 2009

2623 Ronnie Schöb and Marcel Thum, Asymmetric Information Renders Minimum Wages Less Harmful, April 2009

2624 Martin Ruf and Alfons J. Weichenrieder, The Taxation of Passive Foreign Investment Lessons from German Experience, April 2009

2625 Yao Li, Borders and Distance in Knowledge Spillovers: Dying over Time or Dying with Age? - Evidence from Patent Citations, April 2009

2626 Jim Malley and Ulrich Woitek, Technology Shocks and Aggregate Fluctuations in an Estimated Hybrid RBC Model, April 2009

2627 Jin Cao and Gerhard Illing, Endogenous Systemic Liquidity Risk, April 2009

2628 Thiess Buettner and Bjoern Kauder, Revenue Forecasting Practices: Differences across Countries and Consequences for Forecasting Performance, April 2009 